\title{
Activation and release of proteolytic kinin-forming enzymes from rat jejunal loops perfused with hyperosmolar glucose solutions
}

\author{
K. J. WORTHINGTON AND A. CUSCHIERI \\ From the Department of Surgery, Liverpool University, Liverpool, and the Department of Surgery, Ninewells \\ Hospital, Dundee
}

SUMMARY Loops of rat jejunum were perfused in vivo for one hour with de Jalon solutions of increasing glucose concentration. The esterolytic activity of the perfusate and of the extracted loop was measured using benzoyl arginine ethyl ester (BAEe) as substrate. The enzymes lactate dehydrogenase, isocitrate dehydrogenase, and acid phosphatase were measured in the perfusate to estimate the degree of cellular damage. There was a significant depletion of kallikrein from the intestine and a raised level in the perfusate during the hyperosmolar perfusions. No significant difference in the kallikrein levels was observed between the normal jejunum and the iso-osmolar perfused jejunum. Prolonged contact with hyperosmolar solutions caused some cellular damage but this effect appeared to be distinct from the release of kallikrein, which occurred very rapidly during the first 20 minutes. These results confirm that hyperosmolar intestinal contents result in the release of kinin-forming proteolytic enzymes into the circulation and suggest that this mechanism is involved in the syndrome of vasomotor dumping after gastric surgery.

The presence of kinin-forming enzymes in the gastrointestinal tract was first demonstrated by Amundsen and Nustad (1965) in cell homogenates. Since then kininogenases (kinin-forming enzymes) have been identified in the gastrointestinal tract of various species including man (Zeitlin, 1970; Seki et al., 1972) and the activation and release of these enzymes have been implicated in the pathology of some gastrointestinal disorders such as the carcinoid and the post-gastrectomy vasomotor dumping syndromes.

Release of vasoactive kinin peptides have been demonstrated during attacks of vasomotor dumping (Zeitlin and Smith, 1966; MacDonald et al., 1969; Cuschieri and Onobanjo, 1974; Wong et al., 1974; Cuschieri and Worthington, 1976) and this disorder is known to be associated with rapid emptying of the stomach remnant, resulting in hyperosmolar intestinal contents. The in vitro study reported by Zeitlin (1970) showed that activation and release of intestinal kallikrein results from the incubation of fragments of jejunal mucosa in hyperosmolar solutions and suggested hyperosmolar damage to the intestinal mucosal cells as a possible mechanism for

Received for publication 4 November 1976 the release of potent proteolytic enzymes. The present study was designed to test this hypothesis in the in vivo situation.

\section{Methods}

\section{RAT PERFUSION}

Wistar rats (weight range $310-530 \mathrm{~g}$ ) were anaesthetised with intraperitoneal nembutal $(60 \mathrm{mg} / \mathrm{ml}$, $0.1 \mathrm{ml} / \mathrm{g}$ ) and then mounted on a heated operating table $\left(39^{\circ} \mathrm{C}\right)$. The abdomen was shaved and a small midline incision made through the anterior abdominal wall. A segment of small intestine was selected at a fixed distance from the duodenojejunal flexure $(5.0 \mathrm{~cm})$. The selected loop was transected at either end. Two silicone rubber cannulae were inserted at either end and secured in place. The restoration of the continuity of the gastrointestinal tract was effected by an end-to-end anastomosis. The isolated loop was left in the abdominal cavity, which was closed and the two silicone rubber cannulae brought out through the wound at either end. The length of the isolated loop measured along its antimesenteric border was $9.71 \pm 0.84 \mathrm{~cm}$. The loop was then perfused at $39^{\circ} \mathrm{C}$ with one of the de 
Table 1 Concentrations and osmolarity of various de Jalon solutions

\begin{tabular}{|c|c|c|c|c|c|c|c|}
\hline \multirow[t]{2}{*}{ Perfusate } & \multicolumn{2}{|c|}{ m osmol } & \multirow{2}{*}{$\begin{array}{l}\text { Glucose } \\
m M\end{array}$} & \multirow{2}{*}{$\begin{array}{l}\mathrm{NaCl} \\
\mathrm{mM}\end{array}$} & \multirow{2}{*}{$\begin{array}{l}K C l \\
m M\end{array}$} & \multirow{2}{*}{$\begin{array}{l}\mathrm{NaHCO}_{3} \\
\mathrm{mM}\end{array}$} & \multirow{2}{*}{$\begin{array}{l}\mathrm{CaCl} \\
\mathrm{mM}\end{array}$} \\
\hline & $\bar{x}$ & $S D$ & & & & & \\
\hline $\begin{array}{l}\text { De Jalon-1 } \\
\text { De Jalon-2 } \\
\text { De Jalon-3 } \\
\text { De Jalon-4 }\end{array}$ & $\begin{array}{r}259 \cdot 6 \\
534.9 \\
671 \cdot 8 \\
1358.4\end{array}$ & $\begin{array}{r}25 \cdot 39 \\
46 \cdot 97 \\
5 \cdot 01 \\
84 \cdot 8\end{array}$ & $\begin{array}{c}2 \cdot 77 \\
250 \\
334 \\
1000\end{array}$ & $\begin{array}{l}154 \\
154 \\
154 \\
154\end{array}$ & $\begin{array}{l}5 \cdot 6 \\
5 \cdot 6 \\
5 \cdot 6 \\
5 \cdot 6\end{array}$ & $\begin{array}{l}5.95 \\
5.95 \\
5.95 \\
5.95\end{array}$ & $\begin{array}{l}0 \cdot 27 \\
0 \cdot 27 \\
0.27 \\
0 \cdot 27\end{array}$ \\
\hline
\end{tabular}

Jalon solutions shown in Table 1 at a rate of $30.0 \mathrm{ml}$ per hour. The type of de Jalon solution perfused in terms of osmolarity through a given loop was completely randomised. The perfusion was continued for 60 minutes and samples of effluent taken every 20 minutes. At the end of the experiment the perfused loop was excised and the animal killed. The removed loop was then washed in saline, blotted, and weighed. It was minced with scissors and homogenised in glass-distilled water (W/V: 1/10) using a Potter Elvjham-type homogeniser. This was centrifuged at $12000 \mathrm{~g} \times 2 \mathrm{~h}$ in an MSE 25 high-speed centrifuge and the supernatant removed and deep frozen for subsequent assay.

The first 10 samples of extracted loops were treated differently. Before centrifugation each was divided into three equal parts. One third was centrifuged immediately, one was left to autolyse at room temperature overnight, and one was heated at $55^{\circ} \mathrm{C}$ for 10 minutes.

\section{BIOCHEMICAL MEASUREMENTS}

\section{Estimation of esterolytic activity}

This was measured using the benzoyl arginine ethyl ester (BAEe), alcohol dehydrogenase linked method as previously described by Worthington and Cuschieri $(1974,1976)$. In some cases, however, the activity was very low and the method was modified slightly. A sample of the extracted loop $(0.2 \mathrm{ml})$ or perfusate $(0.5 \mathrm{ml})$ was incubated in a cuvette for 15 minutes at $37^{\circ} \mathrm{C}$ with BAEe $(0.2 \mathrm{mg})$ and buffer to give a final volume of $2.85 \mathrm{ml}$. Alcohol dehydrogenase $(0.6 \mathrm{mg})$ and $\mathrm{NAD}^{+}(1.5 \mathrm{mg})$ were then added and the extinction at $366 \mathrm{~nm}$ recorded continually for two minutes. In each case a blank containing no BAEe was used. The spontaneous breakdown of BAEe at this $\mathrm{pH}$ was measured using identical conditions but omitting the enzyme. The effects of the inhibitor Trasylol (1000 KIU) and the inhibitors from ovomucoid and soybean $(1.0 \mathrm{mg})$ were determined. These were added to the mixture in the cuvette before incubation at $37^{\circ} \times 15 \mathrm{~min}$. Each estimation was performed in triplicate.
Measurement of lactate dehydrogenase, isocitrate dehydrogenase (NADP linked) and acid phosphatase The Boehringer Mannheim GMBH Biochemical Test combination kits were used to assay these enzymes. In each case the amount of serum specified was substituted by a similar amount of perfusate.

\section{Other Estimations}

Protein in the perfusate samples was assayed using the method of Lowry et al. (1951) and in the extracted loop samples by the Biuret method as described by Gornall et al. (1949). Bovine serum albumin was used as a standard.

Glucose was measured using the glucose hexokinase Boehringer Mannheim GMBH Biochemical Test combination kit. Sodium and potassium were measured using an EEL 450 flame photometer, the osmolarity of the de Jalon solutions was measured using an Osmette $\mathbf{S}$ osmometer, and haemoglobin was estimated using Hemastix reagent strips (Ames Co.).

\section{Results}

Deep freezing the samples did not cause any loss in enzyme activity if assayed within one month. During the perfusion there was no significant change in the concentration of glucose, sodium, and potassium or the volume of the perfusate. The esterolytic activity was calculated both as international milliunits per $\mathrm{ml}(\mathrm{ImU} / \mathrm{ml})$ and per $\mathrm{mg}$ protein (ImU/mg). The latter value did not appear to be relevant, probably because of a large amount of extraneous protein being present. Neither autolysis nor heating increased the esterolytic activity per $\mathrm{ml}$ of the extracted loop. Both had the effect of reducing the protein content of the extract by as much as 36 to $57 \%$, making the specific enzyme activity much higher. However, from the argument mentioned above and from the fact that the decrease in protein content was variable, thus introducing a greater error when comparing the results, all further work was carried out on the untreated material.

The mean values and standard deviations for esterolytic activity are shown in Table 2 and for the other enzymes in Table 3. For the perfusate these values are for the pooled samples from each experiment. However, the esterolytic activity was consistently highest during the first $\mathbf{2 0}$ minutes, whereas the increase in the concentration of the other enzymes occurred during the last 20 minutes of the perfusion.

The raw data for all the enzyme activities was shown to have a $\log _{10}$ distribution and for the purpose of Student's $t$ test logarithmic transformation of the data was carried out. The $P$ values obtained after 
Table 2 Mean values and standard deviations for esterolytic activity $(\mathrm{ImU} / \mathrm{ml})$ of extracted loop and perfusate

\begin{tabular}{lllllll}
\hline Group & $n$ & \multicolumn{2}{l}{ Extracted loop } & & \multicolumn{2}{l}{ Perfusate } \\
\cline { 2 - 4 } \cline { 6 - 7 } & & $\bar{x}$ & $S D$ & & $\bar{x}$ & $S D$ \\
\hline Normal unperfused & 10 & 98.90 & 42.68 & & & - \\
De Jalon-1 perfused & 10 & 73.74 & 26.29 & & 7.88 & 9.86 \\
De Jalon-2 perfused & 10 & 46.84 & 23.29 & & 28.01 & 27.6 \\
De Jalon-3 perfused & 10 & 53.29 & 21.86 & & 16.83 & 17.73 \\
De Jalon-4 perfused & 10 & 49.99 & 26.63 & & 19.87 & 19.83 \\
\hline
\end{tabular}

Table 3 Mean values for isocitrate dehydrogenase $(I C D H)$, lactate dehydrogenase $(L D H)$, and acid phosphatase of perfusate (expressed as $I m U / m l$ )

\begin{tabular}{|c|c|c|c|c|c|c|c|}
\hline \multirow[t]{2}{*}{ Group } & \multirow[t]{2}{*}{$n$} & \multicolumn{2}{|c|}{$I C D H$} & \multicolumn{2}{|l|}{$L D H$} & \multicolumn{2}{|c|}{ Acid phos. } \\
\hline & & $\bar{x}$ & $S D$ & $\dot{x}$ & $S D$ & $\bar{x}$ & $S D$ \\
\hline $\begin{array}{l}\text { De Jalon-1 perfused } \\
\text { De Jalon-2 perfused } \\
\text { De Jalon-3 perfused } \\
\text { De Jalon-4 perfused }\end{array}$ & $\begin{array}{l}10 \\
10 \\
10 \\
10\end{array}$ & $\begin{array}{r}2 \cdot 86 \\
8 \cdot 28 \\
2 \cdot 85 \\
10 \cdot 59\end{array}$ & $\begin{array}{l}2 \cdot 72 \\
8 \cdot 69 \\
2 \cdot 34 \\
8 \cdot 5\end{array}$ & $\begin{array}{r}57 \cdot 04 \\
268 \cdot 69 \\
307 \cdot 24 \\
229 \cdot 22\end{array}$ & $\begin{array}{r}48 \cdot 89 \\
174 \cdot 61 \\
219 \cdot 70 \\
175 \cdot 32\end{array}$ & $\begin{array}{l}2 \cdot 39 \\
3 \cdot 12 \\
2 \cdot 04 \\
3 \cdot 76\end{array}$ & $\begin{array}{l}1 \cdot 68 \\
4 \cdot 27 \\
1 \cdot 65 \\
4 \cdot 52\end{array}$ \\
\hline
\end{tabular}

performing the $t$ test for unpaired data are shown in Tables 4 and 5 . The test was performed between all the groups but only those in which a significant difference was observed are included in the Tables.

The normal unperfused loop contained the highest esterolytic activity and this was significantly higher than the activity in the loops perfused with hyperosmolar solutions. The esterolytic activity of the de Jalon-1 perfused loop was not significantly lower than the normal group but it was significantly higher than the other perfused loops.

In the perfusate the esterolytic activity was lowest in the de Jalon-1 group and was significantly raised in the de Jalon-2 and 4 groups but not in 3 . Of the three other enzymes studied, lactate dehydrogenase was the only one that was raised during all the hyperosmolar perfusions; isocitrate dehydrogenase was raised with de Jalon-4 solution only.

The correlation coefficient between esterolytic activity and the various other values are shown in Table 6. The only significant correlation appeared to be between isocitrate dehydrogenase and esterolytic activity, and acid phosphatase and esterolytic activity in the perfusate. There was no correlation between the amount of haemoglobin and any of the enzymes.

Trasylol almost completely inhibited the esterolytic activity of both the extracted loop (91.5 $\pm 10.7 \%)$ and the perfusate $(88.7 \pm 15.6 \%)$. The inhibition by soybean and ovomucoid was much more variable, the mean values being $35.6 \pm 16.8 \%$ and $17 \cdot 1 \pm$
Table 4 Probability values (P) for Student's t test for significance for $\log _{10}$ values of esterolytic activity

\begin{tabular}{lccc}
\hline Group & \multicolumn{2}{l}{ Extracted loop } & $\begin{array}{l}\text { Perfusate } \\
\text { De Jalon- 1 } \\
\text { perfused }\end{array}$ \\
\cline { 2 - 4 } & $\begin{array}{l}\text { Normal } \\
\text { Unperfused }\end{array}$ & $\begin{array}{l}\text { De Jalon I } \\
\text { perfused }\end{array}$ & \\
\hline De Jalon-1 perfused & 0.1 & - & - \\
De Jalon-2 perfused & 0.005 & $<0.02$ & 0.05 \\
De Jalon-3 perfused & $<0.001$ & $<0.01$ & $>0.1$ \\
De Jalon-4 perfused & $<0.005$ & $<0.05$ & 0.05 \\
\hline
\end{tabular}

Table 5 Probability values (P) for Student's t test for significance between $\log _{10}$ values of enzyme activities for de Jalon 1 perfused group and other groups

\begin{tabular}{llllll}
\hline & \multicolumn{2}{l}{ Perfusate } & & \multicolumn{2}{l}{ Extracted loop } \\
\cline { 2 - 3 } \cline { 5 - 6 } & $r$ & P & & $r$ & P \\
\hline Glucose & 0.0318 & 0.8 & & 0.227 & 0.2 \\
Esterolytic act. loop & 0.1670 & 0.1 & & & \\
ICDH & 0.4248 & 0.01 & & & \\
LDH & 0.2683 & 0.05 & & & \\
Acid phos. & 0.3499 & 0.05 & & & \\
\hline
\end{tabular}

Table 6 Correlation coefficient $(r)$ and probability values (P) for esterolytic activity of perfusate and extracted loops and various other values

\begin{tabular}{lcll}
\hline Group & ICDH & LDH & Acid phos. \\
\hline De Jalon-2 perfused & $>0.05$ & $<0.001$ & 0.4 \\
De Jalon-3 perfused & 0.7 & $<0.001$ & 0.5 \\
De Jalon-4 perfused & $<0.01$ & $<0.01$ & 0.99 \\
\hline
\end{tabular}

inhibitors were not used with the perfusate because of insufficient samples.

\section{Discussion}

The three enzymes lactate dehydrogenase, isocitrate dehydrogenase, and acid phosphatase were measured in an attempt to estimate the amount of cellular disruption occurring during the perfusions. The enzymes lactate dehydrogenase and isocitrate dehydrogenase (NADP linked) are thought to occur predominantly in the soluble fraction and acid phosphatase in the lysosomal fraction of the cell (Dixon and Webb, 1962; de Duve et al., 1962). During all the hyperosmolar perfusions the significantly raised levels of lactate dehydrogenase indicated that a certain degree of cellular damage had occurred. However, this appeared to be an all-or-none relationship, there being no further release of this enzyme on increasing the osmolarity above 530 mosmol.

Isocitrate dehydrogenase, which is also a soluble enzyme, did not follow the same pattern, although the level in the de Jalon-4 perfused group was 
significantly higher than the level in the de Jalon-1 group. From the values in Table 3 , it can be seen that there is no relationship between the amount of isocitrate dehydrogenase released and the osmolarity or glucose concentration of the perfusate. It is therefore not possible to use this enzyme as an index of cellular damage caused by high glucose concentrations. The level of acid phosphatase did not significantly change during the perfusion, indicating that little lysosomal damage had occurred.

The esterolytic activity found in the perfusate during the hyperosmolar perfusions was raised, although not significantly so, in the de Jalon-3 group. The results differ from those observed by Zeitlin (1970) who showed a progressive increase in the release of kallikrein into the incubate with increasing osmolarity. However, the conditions of this experiment differed considerably from our own. The work was carried out with small prisms of tissue $(0.4 \mathrm{~mm})$ which did not represent the true in vivo situation where, in fact, one would expect the enzyme kallikrein to be released into the blood stream to act upon its plasma substrate, kininogen. Therefore, the release into the lumen of the intestine in vivo should not be considerable. A better indication would be in the depletion of kallikrein from the intestine itself and this is what the present results indicate. The findings of the present study show that activation of kallikrein occurs when loops of intestine are perfused with solutions with an osmolarity outside the normal physiological range. However, no further increase in the release of proteolytic activity was found when the osmolarity of the perfusate was increased from 530 to 1350 mosmol. Like lactate dehydrogenase, the release of proteolytic enzymes in response to perfusion with hyperosmolar solutions seems to be an all-or-none phenomenon.

The release of kallikrein into the perfusate was rapid, occurring in the first 20 minutes of the perfusion, whereas cellular damage as indicated by lactate dehydrogenase occurred only after 40 minutes of perfusion. Therefore, the effect of hyperosmolar solutions on the release of proteolytic enzymes appears to be specific and may not be ascribed directly to cellular damage.

The correlation observed between the release of proteolytic activity and the two enzymes isocitrate dehydrogenase and acid phosphatase, while in no way related to the glucose concentration, may be due to some of the jejunal membranes being more permeable to the passage of enzymes than others. The lack of correlation between any of the enzymes and the haemoglobin content rules out the possibility that this relationship is due to enzymes from the blood rather than the jejunum.

The inhibition profile for the enzyme extracted from the jejunal loop indicates that approximately $17 \%$ of the enzyme activity was due to plasma kallikrein or trypsin, $8 \%$ due to plasmin, and the remaining $75 \%$ of the activity due to intestinal kallikrein (Vogel and Werle, 1970; Zeitlin, 1972). As these tissues were not blood free, one would expect some contamination with plasma enzymes. There was no significant difference between the inhibition patterns of each group.

The effects of hyperosmolar solutions upon the rat jejunum in vivo, when projected to the human situation, reinforce the findings of various workers on the role of the kinin-kallikrein system in the dumping syndrome. In this syndrome the rapid emptying of the stomach remnant leads to a situation where the intestinal contents are hyperosmolar.This study has shown that hyperosmolar intestinal contents can act as a mechanism for the release of intestinal kinin-forming enzymes such as kallikrein. The findings from this study have, also, practical implications with regard to enteral hyperalimentation as most elemental diets are hyperosmolar.

We would like to thank Mrs I. M. Tyrrell for her invaluable technical assistance. This work was supported by a grant from the Wellcome Trust.

\section{References}

Amundsen, E., and Nustad, K. (1965). Kinin-forming and destroying activities of cell homogenates. Journal of Physiology, 179, 479-488.

Cuschieri, A., and Onabanjo, O. A. (1971). Kinin release after Gastric Surgery. British Medical Journal, 3, 565-566.

Cuschieri, A., and Worthington, K. J. (1976). Kinin levels in the peripheral venous blood of patient with severe vasomotor dumping before and after revisional surgery. British Journal of Surgery, 63, 210-212.

de Duve, C., Wattiaux, R., and Baudhuin, P. (1962). Distribution of enzymes between subcellular fractions in animal tissues. Advances in Enzymology, 24, 291-358.

Dixon, M., and Webb, E. C. (1964). Enzymes and cell structure. In Enzymes, 2nd edn., pp. 621-636. Longmans, Green: London.

Gornall, A. G., Bardawill, C. J., and David, M. M. (1949). Determination of serum proteins by means of the biuret reaction. Journal of Biological Chemistry, 177, 751-766.

Lowry, O. W., Rosebrough, N. J., Farr, A. L., and Randall, R. J. (1951). Protein measurement with the folin phenol reagent. Journal of Biological Chemistry, 193, 265-275.

MacDonald, J. M., Webster, M. M. Jr., Tennyson, C. H., and Drapanas, T. (1969). Serotonin and bradykinin in the dumping syndrome. American Journal of Surgery, 117, 204-213.

Seki, T., Nakajima, T., and Erdos, E. G. (1972). Colon kallikrein-its relation to the plasma enzyme. Biochemical Pharmacology, 21, 1227-1235.

Vogel, R., and Werle, E. (1970). Kallikrein inhibitors. In Handbook of Experimental Pharmacology, vol. 25, pp. 213-239. Edited by E. G. Erdos. Springer: Berlin.

Wong, P. Y., Talamo, R. C., Babior, B. M., Raymond, G. G., and Colman, R. W. (1974). Kallikrein-kinin system in post-gastrectomy dumping syndrome. Annals of Internal 
Medicine, 80, 577-581.

Worthington, K. J., and Cuschieri, A. (1974). A study on the kinetics of pancreatic kallikrein with the substrate benzoyl arginine ethyl ester using a spectrophotometric assay. Clinica Chimica Acta, 52, 129-136.

Worthington, K. J., and Cuschieri, A. (1976). Estimation of plasma esterolytic activity and its in vitro inhibition by proteinase inhibitors during acute pancreatitis in the human. British Journal of Experimental Pathology, 57
165-169.

Zetilin, I. J. (1970). Kinin release associated with the gastrointestinal tract. Advances in Experimental Medicine and Biology, 8, 329-339.

Zeitlin, I. J., and Smith, A. N. (1966). 5-hydroxyindoles and kinins in the carcinoid and dumping syndromes. Lancet, 2 , 986-991.

Zeitlin, I. J. (1972). Rat intestinal kallikrein. Advances in Experimental Medicine and Biology, 21, 289-296.

\section{The March 1977 Issue}

\section{THE MARCH 1977 ISSUE CONTAINS THE FOLLOWING PAPERS}

Plasma levels and intestinal absorption of 25hydroxyvitamin $\mathrm{D}$ in patients with small bowel resection JULIET E. COMPSTON AND B. CREAMER

Mechanism of malabsorption in giardiasis: a study of bacterial flora and bile salt deconjugation in upper jejunum B. N. TANDON, R. K. TANDON, B. K. SATPATHY, AND SHRINIWAS

Effect of iron and protein deficiency on the expulsion of Nippostrongylus brasiliensis from the small intestine of the rat T. D. BOLIN, A. E. DAVIS, A. G. CUMMINS, V. M. DUNCOMBE, AND J. D. KELLY

Effect of aspirin on intestinal absorption of glucose, sodium, and water in man C. ARVANITAKIS, G-H. CHEN, J. FOLSCROFT, AND N. J. GREENBERGER

Plasma secretin and pancreatic bicarbonate response to exogenous secretin in man W. H. HÄCKI, S. R. BLOOM, P. MITZNEGG, W. DOMSCHKE, S. DOMSCHKE, D. BELOHLAVEK, L. DEMLING, AND E. WÜNSCH

Chronic pancreatitis: a cause of cholestasis J. SCOTT, J. A. SUMMERFIELD, E. ELIAS, R. DICK, AND SHEILA SHERLOCK

\section{Models of gastric emptying D. F. STUBBS}

Relationship between undissociated acidity of gastric juice and gastric protein secreted in response to graded doses of pentagastrin in duodenal ulcer patients T. POPIELA, Z. SZAFRAN, HALINA SZAFRAN, AND M. KOMOROWSKA

Gastric gland metaplasia in the small and large intestine I. YOKOYAMA, S. KOZUKA, K. ITO, K. KUBOTA, Y. YOKOYAMA, AND T. KONDO
Glucosamine synthetase activity of the colonic mucosa in ulcerative colitis and Crohn's disease M. J. GOODMAN, P. W. KENT, AND S. C. TRUELOVE

Glucosamine synthetase activity of the colonic mucosa in membranous colitis M. J. GOODMAN, P. W. KENT, AND S. C. TRUELOVE

Immunoprophylaxis and therapy of grafted rat colonic carcinoma M. S. MARTIN, F. MARTIN, E. JUSTRABO, M. F. MICHEL, AND A. LAGNEAU

Ileorectal anastomosis in patients with Crohn's disease of the colon G. FLINT, R. STRAUSS, N. PLATT, AND L. WISE

Effect of sodium chenodeoxycholate on oxalate absorption from the excluded human colon-a mechanism for 'enteric' hyperoxaluria P. D. FAIRCLOUGH, T. G. FEEST, V. S. CHADWICK, AND M. L. CLARK

Incidence and immunochemical features of serum cryoglobulin in chronic liver disease G. P. JORI, G. BUONANNO, F. D'ONOFRIO, A. TIRELLI, F. GONNELLA, AND $S$. GENTILE

Immune responses to the hepatitis $B$ surface antigen and liver-specific lipoprotein in acute type $B$ hepatitis W. M. LEE, W. D. REED, C. G. OSMAN, J. VAHRMAN, A. J. ZUCKERMAN, A. L. W. F. EDDLESTON, AND ROGER, WILLIAMS

Notes and activities

Books

Copies are still available and may be obtained from the PUBLISHING MANAGER, BRITISH MEDICAL ASSOCIATION, TAVISTOCK SQUARE, WC1H 9JR, price $£ 2 \cdot 75$, including postage 